\title{
JV TASK 21 - RECOVERY OF LACTIC ACID FROM AMERICAN CRYSTAL SUGAR COMPANY WASTEWATER
}

Final Topical Report

(for the period October 25, 1999 through January 31, 2001)

Prepared for:

AAD Document Control

National Energy Technology Laboratory

U.S. Department of Energy

PO Box 10940, MS 921-143

Pittsburgh, PA 15236-0940

DOE Cooperative Agreement No. DE-FC26-98FT40321

Performance Monitor: Ms. Lynn Brickett

Prepared by:

Daniel J. Stepan

Edwin S. Olson

Richard E. Shockey

Bradley G. Stevens

John R. Gallagher

Energy \& Environmental Research Center

University of North Dakota

PO Box 9018

Grand Forks, ND 58202-9018 


\section{EERC DISCLAIMER}

LEGAL NOTICE This research report was prepared by the Energy \& Environmental Research Center (EERC), an agency of the University of North Dakota, as an account of work sponsored by the U.S. Department of Energy (DOE). Because of the research nature of the work performed, neither the EERC nor any of its employees makes any warranty, express or implied, or assumes any legal liability or responsibility for the accuracy, completeness, or usefulness of any information, apparatus, product, or process disclosed, or represents that its use would not infringe privately owned rights. Reference herein to any specific commercial product, process, or service by trade name, trademark, manufacturer, or otherwise does not necessarily constitute or imply its endorsement or recommendation by the EERC.

\section{DISCLAIMER}

This report was prepared as an account of work sponsored by an agency of the United States Government. Neither the United States Government, nor any agency thereof, nor any of their employees makes any warranty, express or implied, or assumes any legal liability or responsibility for the accuracy, completeness, or usefulness of any information, apparatus, product, or process disclosed or represents that its use would not infringe privately owned rights. Reference herein to any specific commercial product, process, or service by trade name, trademark, manufacturer, or otherwise does not necessarily constitute or imply its endorsement, recommendation, or favoring by the United States Government or any agency thereof. The views and opinions of authors expressed herein do not necessarily state or reflect those of the United States Government or any agency thereof.

This report is available to the public from the National Technical Information Service, U.S. Department of Commerce, 5285 Port Royal Road, Springfield, VA 22161; phone orders accepted at (703) $487-4650$.

\section{ACKNOWLEDGMENT}

This report was prepared with the support of DOE National Energy Technology Laboratory Cooperative Agreement No. DE-FC26-98FT40321. However, any opinions, findings, conclusions, or recommendations expressed herein are those of the authors(s) and do not necessarily reflect the views of DOE. 


\section{TABLE OF CONTENTS}

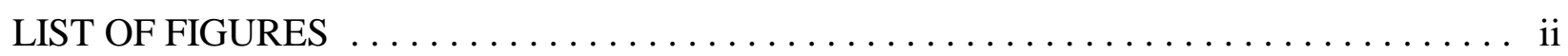

LIST OF TABLES $\ldots \ldots \ldots \ldots \ldots \ldots \ldots \ldots \ldots \ldots \ldots \ldots \ldots \ldots \ldots \ldots \ldots \ldots$

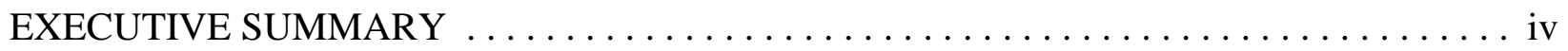

1.0 INTRODUCTION/BACKGROUND $\ldots \ldots \ldots \ldots \ldots \ldots \ldots \ldots \ldots \ldots \ldots \ldots \ldots$

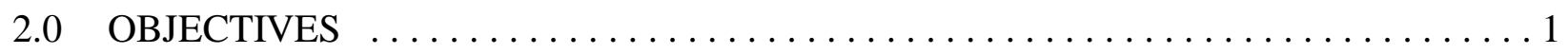

3.0 PROCESS DEVELOPMENT $\ldots \ldots \ldots \ldots \ldots \ldots \ldots \ldots \ldots \ldots \ldots \ldots \ldots \ldots \ldots \ldots$

4.0 FREEZE CONCENTRATION $\ldots \ldots \ldots \ldots \ldots \ldots \ldots \ldots \ldots \ldots \ldots \ldots \ldots \ldots$

4.1 Freeze Concentration of Fermentation Effluent $\ldots \ldots \ldots \ldots \ldots \ldots \ldots \ldots \ldots$

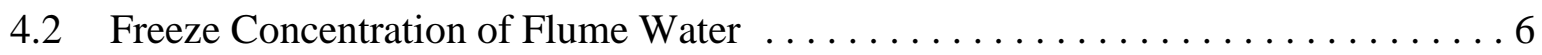

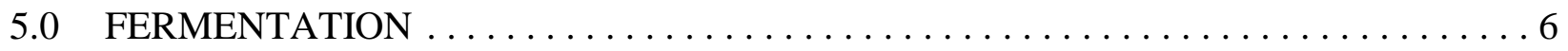

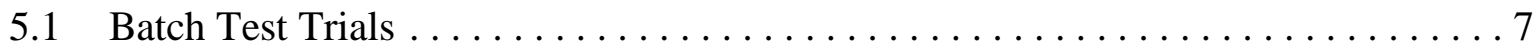

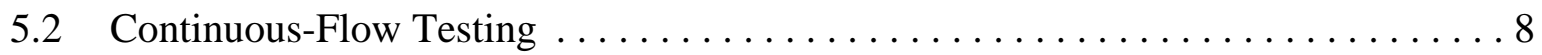

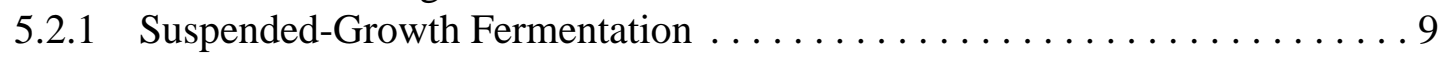

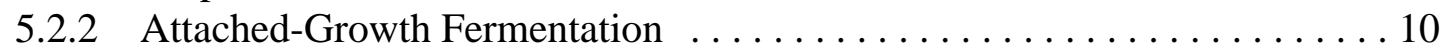

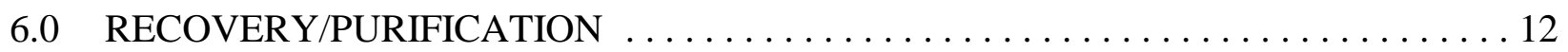

6.1 Conventional Calcium Lactate Formation and Acidification . . . . . . . . . . . 12

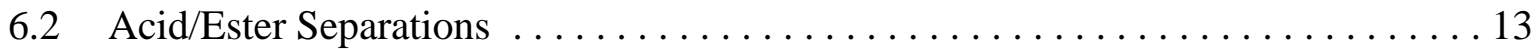

6.3 Sodium Recycle, Calcium Lactate Precipitation $\ldots . \ldots \ldots \ldots \ldots \ldots \ldots \ldots$

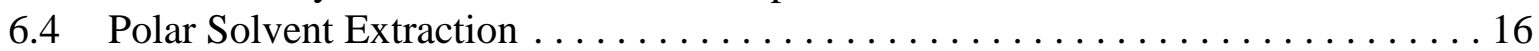

6.5 Esterification/Distillation Combined with Extraction $\ldots \ldots \ldots \ldots \ldots \ldots \ldots \ldots$

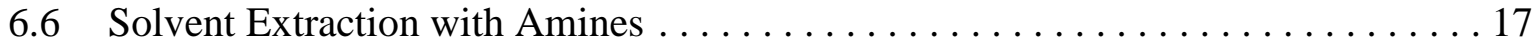

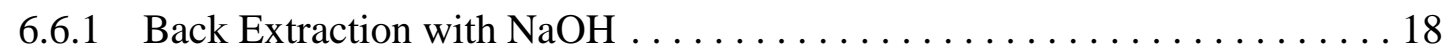

6.6.2 Thermal Cracking of Ammonium Lactate Solution . . . . . . . . . . . 18

6.6.3 Esterification of Ammonium Lactate Solution . . . . . . . . . . . . . 18

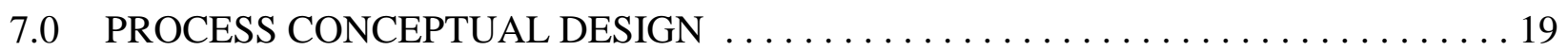

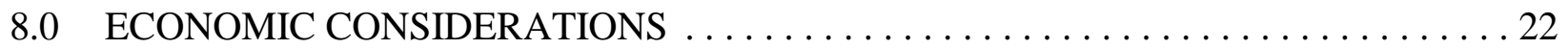

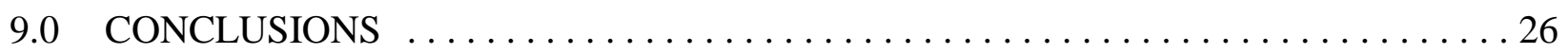




\section{LIST OF FIGURES}

1 Flume water COD - East Grand Forks, Minnesota, 1999-2000 campaign . . . . . . . . . 2

2 ACS Anamet wastewater treatment and lactic acid recovery $\ldots \ldots \ldots \ldots \ldots \ldots$

3 Lactic acid production and recovery process $\ldots \ldots \ldots \ldots \ldots \ldots \ldots \ldots$

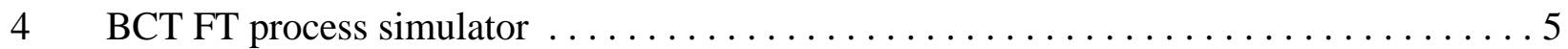

5 Organic acid production - ACS flume water at $98^{\circ} \mathrm{F}\left(37^{\circ} \mathrm{C}\right)$ and $\mathrm{pH} 5 \ldots \ldots$

6 Suspended-growth fermentation process diagram $\ldots \ldots \ldots \ldots \ldots \ldots \ldots \ldots$

7 Attached-growth fermentation process diagram $\ldots \ldots \ldots \ldots \ldots \ldots \ldots \ldots \ldots$

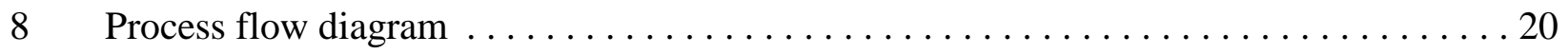




\section{LIST OF TABLES}

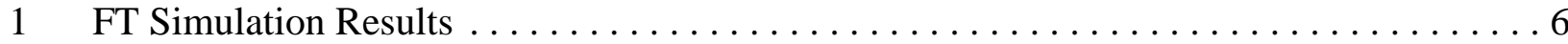

2 Performance Summary - Suspended-Growth Fermentation

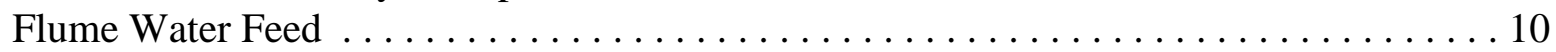

3 Performance Summary - Suspended-Growth Fermentation

Freeze-Concentrated Flume Water Feed $\ldots \ldots \ldots \ldots \ldots \ldots \ldots \ldots \ldots \ldots \ldots \ldots$

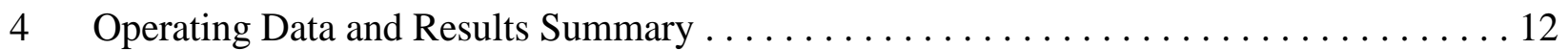

5 Pressure Filtration of Calcium Gel Acid Concentrations in Filtrate . . . . . . . . . . . . . 15

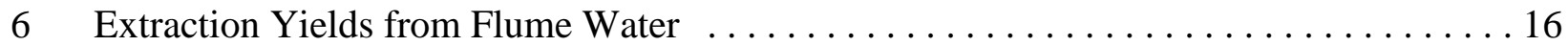

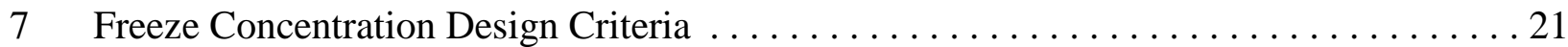

$8 \quad$ Fermentation Process Design Criteria $\ldots \ldots \ldots \ldots \ldots \ldots \ldots \ldots \ldots \ldots \ldots \ldots \ldots \ldots \ldots \ldots \ldots$

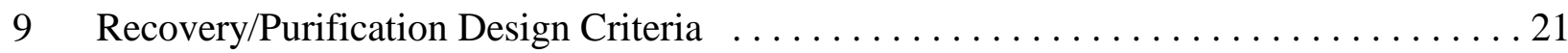

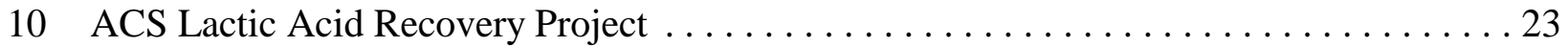

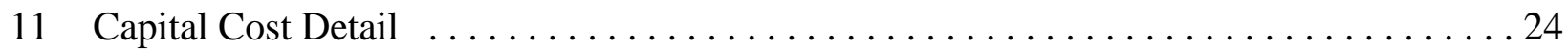

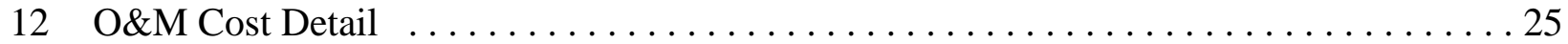




\section{RECOVERY OF LACTIC ACID FROM AMERICAN CRYSTAL SUGAR COMPANY WASTEWATER}

\section{EXECUTIVE SUMMARY}

American Crystal Sugar Company (ACS) produces nearly 24 million cwt of sugar each year from its five factories in the Red River Valley. Each of the factories generates up to $1 \mathrm{mgd}$ of highstrength wastewater that has historically been problematic with respect to treatment and odor generation. This presents a major challenge to ACS, from both an economic and environmental perspective. The Energy \& Environmental Research Center (EERC) has developed a process concept that takes advantage of the high volumes of carbohydrate wastewater to produce high-value, environmentally friendly products, while simultaneously providing environmental benefits through enhancing the operation of the existing wastewater treatment system and reducing the potential for odor generation. The overall process consists of freeze-concentrating carbohydrates from mud press wastewater, followed by controlled fermentation to produce lactic acid and chemical conversion to produce lactic acid esters.

Using natural freezing conditions in the region, freeze-thaw (FT) is a key technology to economically concentrate the carbohydrates and reduce the required size and efficiency of downstream unit operations. A majority of the water, approximately $80 \%$, is frozen as relatively pure ice crystals that are recovered as clean water when the ice pile melts in the spring. A concentrated carbohydrate stream (20\% of the original wastewater flow) is directed to a fermentation process where the sugars are biologically converted to lactic acid. Using indigenous microorganisms, the EERC has determined fermentation conditions to preferentially form lactic acids while minimizing the production of undesirable organic acids that are responsible for foul odors. Effluent from the fermenter is directed to a proprietary recovery process where lactate is extracted and esters are produced. Lactate esters represent alternative or replacement solvents for conventional hazardous industrial solvents and can be utilized as intermediates for the production of other chemicals.

The lactate esters are good solvents for polymers and resins and could replace ketones and other polar solvents used in the polymer industry. Because of their low volatility and viscositylowering properties, they will be especially useful for inks for jet printers, alkyd resins, and highsolid paints. Owing to their efficiency in dissolving salts and flux as well as oils and sealants, lactate esters can be used in cleaning circuit boards and machine and engine parts. Unlike conventional solvents, lactate esters exhibit low toxicity, are biodegradable, and are not hazardous air pollutants. Another potential market is polymers prepared from lactic acid. These are called polylactides and are a type of polyester. Thermoplastics of this type have a variety of uses, including moldings, fibers, films, and packaging of both manufactured goods and food products. Polylactides form tough, orientable, self-supporting thin films and have, therefore, been used for adhesives, safety glass, and finishes.

The EERC process is projected to produce approximately $200,000 \mathrm{lb}$ per day of lactate esters from wastewater at a single factory at costs that compete with conventional solvents. Preliminary economic analyses project production costs at around $\$ 0.50 / \mathrm{lb}$, with current market prices ranging from $\$ 0.60$ to $\$ 1.74$ per pound of ester. 


\section{RECOVERY OF LACTIC ACID FROM AMERICAN CRYSTAL SUGAR COMPANY WASTEWATER}

\subsection{INTRODUCTION/BACKGROUND}

American Crystal Sugar Company (ACS) produces nearly 24 million cwt of sugar each year from its five factories in the Red River Valley of western Minnesota and eastern North Dakota. Each of the factories generates up to 1 million gallons per day (mgd) of high-strength wastewater that has historically been problematic with respect to treatment and odor generation. This presents a major challenge to ACS, from both an economic and environmental perspective. The Energy \& Environmental Research Center (EERC) has developed a process concept that takes advantage of the high volumes of carbohydrate wastewater to produce high-value, environmentally friendly products, while simultaneously providing environmental benefits by enhancing the operation of the existing wastewater treatment system and reducing the potential for odor generation.

Factory visits were conducted to review wastewater handling and treatment at the respective factories in Moorhead, Crookston, and East Grand Forks, Minnesota, and Hillsboro and Drayton, North Dakota. Available operational data from the factories were also reviewed. The discussion with ACS factory operations personnel and the data review resulted in the selection of flume water as the target water for this study. However, pulp press water and even spoiled beets were other candidate waste streams that were identified as having a high potential for conversion to lactic acid products. Flume water characteristics change throughout the beet- processing campaign, beginning with relatively low organic content, as measured by chemical oxygen demand (COD) in September, at the start of the campaign. The flume water COD continues to increase throughout the campaign and is in the 70,000-mg/L range by the end of the campaign in May. Figure 1 illustrates flume water COD from the East Grand Forks, Minnesota, factory from the 1999-2000 campaign. Control of bacterial growth in the flume water and potential infection within the plant is accomplished through $\mathrm{pH}$ control. Lime is added to the flume water to maintain a $\mathrm{pH}$ in the range of $10-11$. Flume water $\mathrm{pH}$ is also shown in Figure 1.

Most of the factories either are or are planning on using an Anamet ${ }^{\mathrm{TM}}$ wastewater treatment methodology for the treatment of flume water. The Anamet ${ }^{\mathrm{TM}}$ process consists of an anaerobic contact process to convert a majority of sugars and other contaminants to methane, followed by aerobic treatment to produce a water of discharge quality. Lactic acid recovery, integrated in existing operations, is illustrated in Figure 2.

\subsection{OBJECTIVES}

The overall goal of this effort was to develop data to evaluate the technical and economic feasibility of producing and recovering lactic acid products from wastewater produced during the 


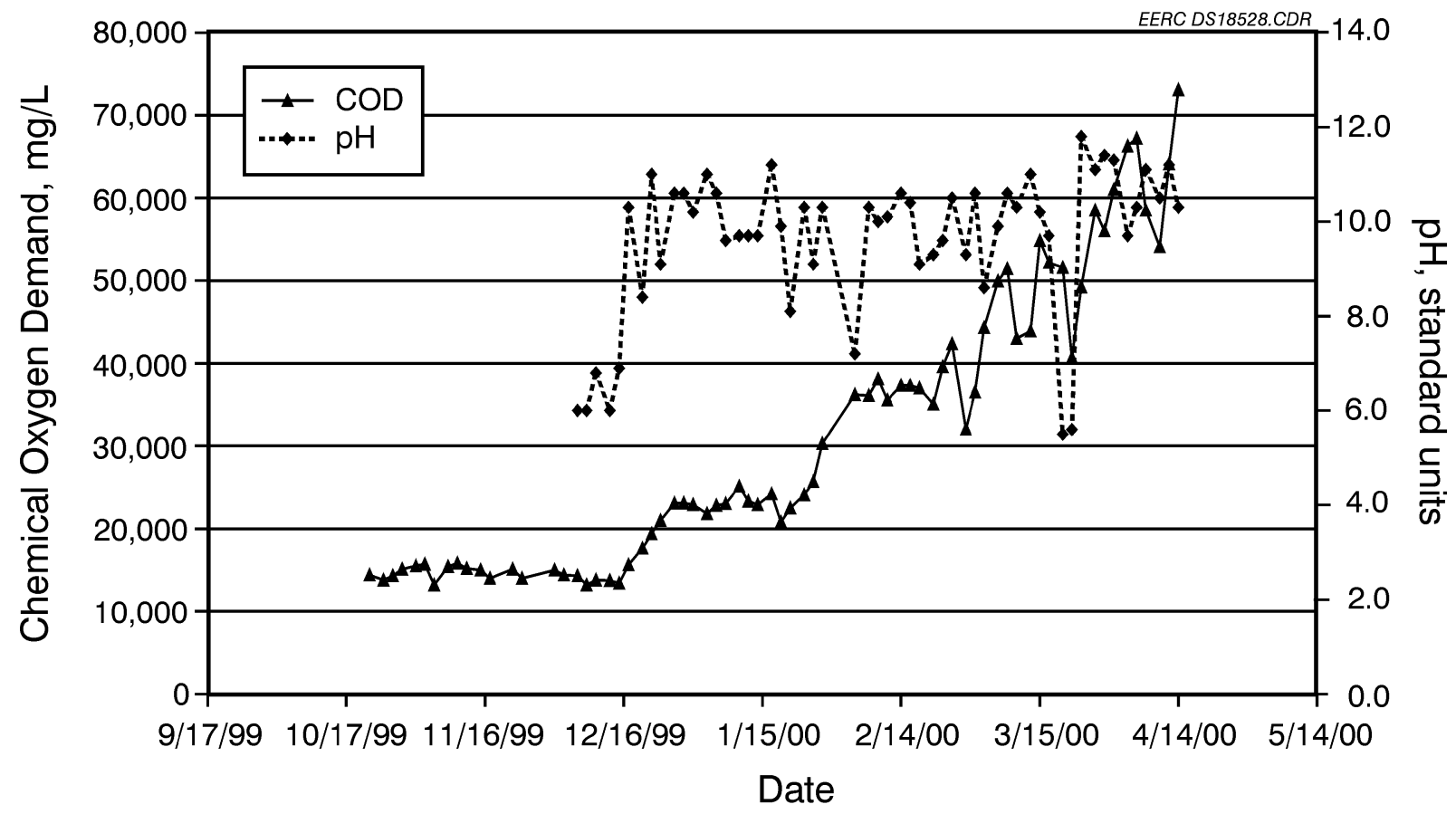

Figure 1. Flume water COD - East Grand Forks, Minnesota, 1999-2000 campaign.

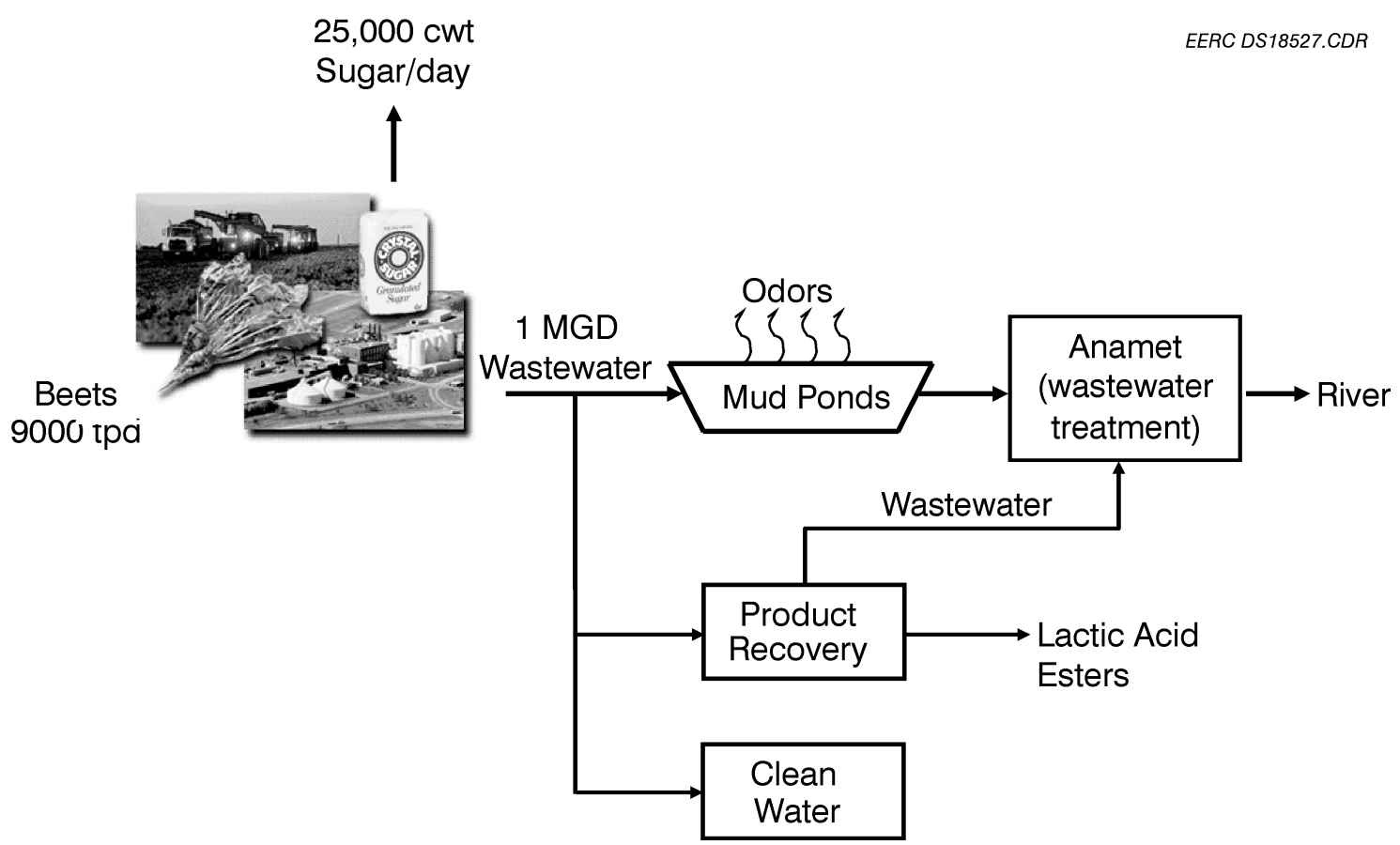

Figure 2. ACS Anamet wastewater treatment and lactic acid recovery. 
refining of beet sugar. Specific project objectives were to develop a process of integrated unit operations and define preliminary engineering data through laboratory-scale testing and analysis that would allow for a cost-benefit analysis.

\subsection{PROCESS DEVELOPMENT}

Throughout the process development effort, several technical and operational issues were identified. The overall process that was developed, illustrated in Figure 3, consists three main unit operations: 1) freeze-concentrating carbohydrates from mud press wastewater, 2) controlled fermentation to produce lactic acid, and 3) chemical conversion to produce lactic acid esters.

Using natural freezing conditions in the region, FT is a key technology used to economically concentrate the carbohydrates and reduce the required size and efficiency of downstream unit operations. A majority of the water, approximately $80 \%$, is frozen as relatively pure ice crystals that are recovered as clean water when the ice pile melts in the spring. A concentrated carbohydrate stream ( $20 \%$ of the original wastewater flow) is directed to a fermentation process where the carbohydrates are biologically converted to lactic acid. Effluent from the fermenter is directed to the recovery and purification process where lactate is extracted and esters are produced.

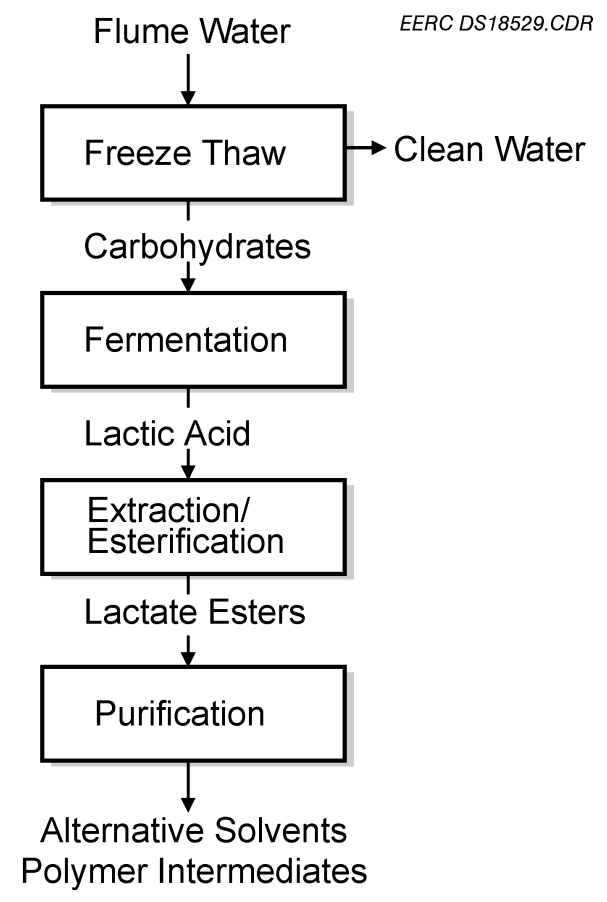

Figure 3. Lactic acid production and recovery process. 


\subsection{FREEZE CONCENTRATION}

Freeze concentration is an established methodology for water purification. As a solution freezes, ice crystals of relatively pure water are formed. Dissolved matter is then concentrated in a brine that has a freezing point less than $32^{\circ} \mathrm{F}\left(0^{\circ} \mathrm{C}\right)$. Further reduction in temperature will result in additional ice formation and a more concentrated brine as long as the freezing temperature of the brine has not been achieved. Freezing is a relatively cost-effective method of concentrating desired constituents in a brine. Only $144 \mathrm{Btu} / \mathrm{lb}$ are required to freeze water, as opposed to $1000 \mathrm{Btu} / \mathrm{lb}$ required to evaporate water, a widely used concentration technique.

The cold winter temperatures of the northern Great Plains make this region ideally suited to using natural freeze concentration techniques to produce and recover desired constituents for ACS wastewaters. Two different freeze concentration scenarios were evaluated: the freeze concentration of lactic and other organic acids (fermentation effluent) and freeze concentration of carbohydrates (flume water).

\subsection{Freeze Concentration of Fermentation Effluent}

Approximately 17 gallons of fermented flume was used in a simulation of freeze concentration to confirm the ability of the FT process to concentrate desired constituents and determine the volumetric partitioning. The FT process simulation was conducted by BC Technologies (BCT) in Laramie, Wyoming. The simulator unit (Figure 4) has computer-operated temperature control and data acquisition to simulate daily temperature cycles typical of the East Grand Forks, Minnesota, area.

The simulation procedure was as follows:

1. Initially, the simulator feed water container was charged with a known volume of ACS flume water.

2. The refrigeration unit controls were programmed to simulate the monthly average daily temperature cycles of the desired atmospheric conditions typical of the East Grand Forks, Minnesota, area. The temperature in the refrigeration unit was logged hourly. The conditions for each month with subfreezing temperatures were run for a 72-hour duration, making the total time of simulation testing approximately 24 days.

3. Water was pumped automatically from the feed water container to the freezing pad when the ambient temperature in the simulator promotes freezing, thus forming an ice pile.

4. Runoff from the freezing pad was automatically diverted to either the treated water or brine pond, based on electrical conductivity (EC). When the simulator temperature promoted freezing, runoff from the pad had concentrated contaminant values (higher EC) and was diverted to the brine pond. When the temperature promoted melting, runoff from the pad had reduced contaminant values (lower EC) and was diverted to the treated-water pond. 


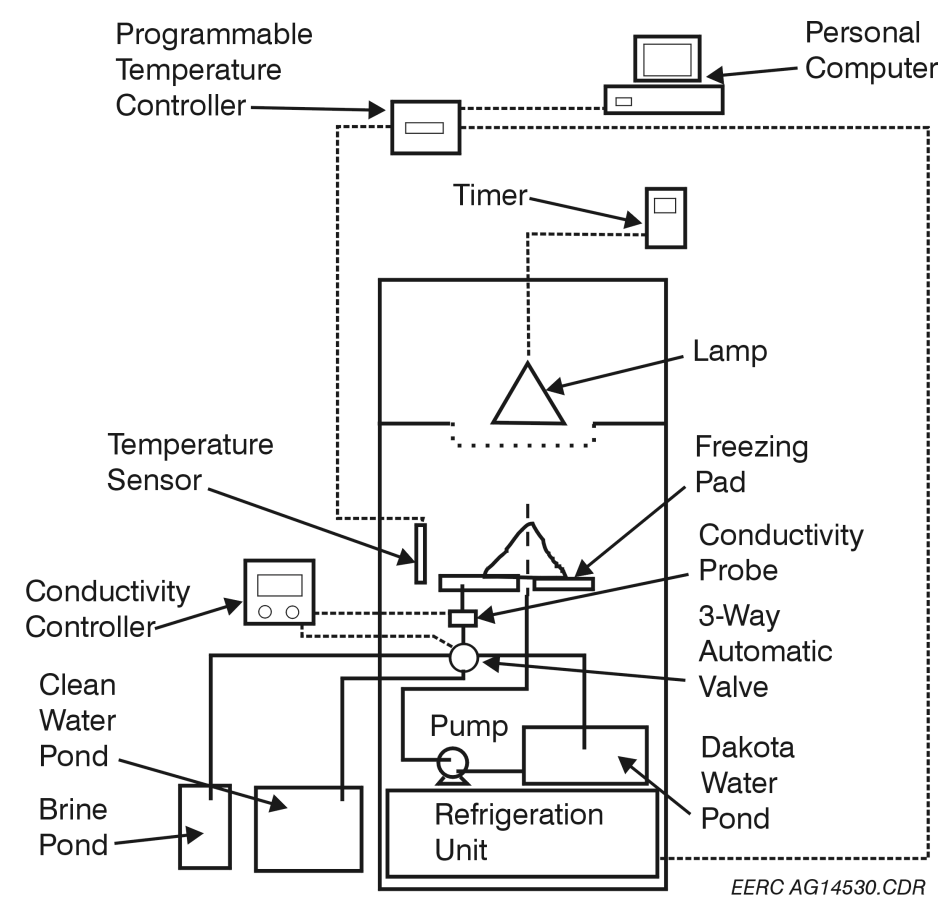

Figure 4. BCT FT process simulator.

5. As needed, makeup water was added to the feed water container. Amounts of contaminated water added and treated water generated were recorded. Heavy brine produced was collected during the experiment, and intermediate brine produced was recycled to the feed water pond for refreezing.

6. Upon completion of the simulation, composite samples of the clean water and brine were collected for analysis.

The resulting process waters from the FT simulation were collected as brine (concentrated product), an intermediate water, and treated water, depending on EC. The results of the FT simulation are shown in Table 1. The simulation resulted in $77 \%$ of the lactic acid being concentrated in $12.5 \%$ of the original sample volume. Greater than $54 \%$ of the original volume resulted as treated water, with $3 \%$ of the original lactic acid. Over $27 \%$ of the original volume of water in the simulation resulted as an intermediate process stream that contained $20 \%$ of the lactic acid.

It can be anticipated, based on a comparison of previous simulation and field demonstration data using Devils Lake water, that a much higher volume percentage of treated water would result along with more concentrated brine and a greatly reduced volume of the intermediate stream. With the better process control that can be achieved during full-scale operation, we would predict a treated-water volume of $80 \%$ to $85 \%$ of the initial feed volume, with a brine being $15 \%$ to $20 \%$ of the initial volume. 
TABLE 1

FT Simulation Results

\begin{tabular}{lccc}
\hline Water Type & $\begin{array}{c}\text { Volumetric Partition, } \\
\% \text { of total volume }\end{array}$ & $\begin{array}{c}\text { Electrical Conductivity, } \\
\mu \mathrm{S} / \mathrm{cm}\end{array}$ & $\begin{array}{c}\text { Lactic Acid, } \\
\%\end{array}$ \\
\hline Flume Water Feed & 100 & 17,910 & 100 \\
Brine & 12.5 & 44,200 & 77 \\
Intermediate & 27.2 & 14,658 & 20 \\
Treated Water & 54.4 & 1564 & 3 \\
\hline
\end{tabular}

A large batch of freeze-concentrated fermentation effluent was prepared for use in lactic acid recovery testing (discussed in Section 6.0 of this report) as well as to confirm the results of the FT simulation. Fifty gallons of fermented flume water was subjected to static freezing. During the static freeze testing, it was observed that the lactic acid concentrate (brine) separates readily from the ice, but left behind a solid precipitate on the ice. Analysis showed the precipitate material to be relatively pure calcium lactate. A maximum brine lactic concentration obtainable was approximately $4 \%$; the solubility of calcium lactate at $32^{\circ} \mathrm{F}\left(0^{\circ} \mathrm{C}\right)$. The precipitate was subsequently attributed to the use of lime for $\mathrm{pH}$ control during fermentation. To overcome issues related to the calcium lactate precipitation, an alternative recovery scheme was investigated, sodium recycle for $\mathrm{pH}$ control coupled with calcium lactate precipitation for lactic acid recovery. However, there were also issues inherent with that process (Section 6). Subsequently, a scheme was conceived whereby freeze concentration of the carbohydrates in the flume water was the first unit operation in the overall process.

\subsection{Freeze Concentration of Flume Water}

Because of issues related to calcium lactate precipitation that occurs during freeze concentration of fermented flume water and difficulties associated with recycling a sodium base for fermentation $\mathrm{pH}$ control, investigations were conducted using the FT process to concentrate carbohydrates in flume water prior to fermentation. This procedure effectively reduces the volume of water that is subsequently fermented, reducing reactor volume requirements.

A large batch of freeze-concentrated flume water was prepared for use in fermentation test trials (Section 5.0) and to verify the ability of the FT process to concentrate carbohydrates in the flume water. Freeze-concentrating flume water resulted in an increase in carbohydrate level from $3 \%$ to $5 \%$ in flume water to greater than $24 \%$ carbohydrate level in the FT brine.

\subsection{FERMENTATION}

Fermentation is the conversion of sugars to organic acids and alcohols. Organic acid production results in the formation of lactic, acetic, propionic, and butyric acids. The objectives of 
the fermentation experiments were to 1) define operational parameters that result in the highest overall production of lactic acid, while minimizing the production of the more undesirable odorcausing acids such as acetic, propionic, and butyric acids and 2) develop preliminary engineering design data for the fermentation unit operation. Batch test trials defined $\mathrm{pH}$ and temperature relationships, and continuous flow reactors were used to develop preliminary engineering design parameters.

\subsection{Batch Test Trials}

Preliminary batch test fermentation trials were conducted to define operational parameters for $\mathrm{pH}$, temperature, and retention times, important control parameters that affect fermentation products. Flume water samples of $100 \mathrm{~mL}$ each were added to shake flasks under varying conditions of temperature and $\mathrm{pH}$. Two different temperatures were evaluated: $77^{\circ} \mathrm{F}\left(25^{\circ} \mathrm{C}\right)$ (room temperature) and $98^{\circ} \mathrm{F}\left(37^{\circ} \mathrm{C}\right)$ (current wastewater heat exchange temperature at ACS) along with three different pH conditions: 5, 7, and 11. Tests were conducted using indigenous microorganisms; the samples were not innoculated with additional bacteria during these tests. The samples were allowed to ferment under the respective conditions with daily adjustment of $\mathrm{pH}$ using sodium hydroxide. Samples were collected over time and analyzed for organic acid content using high-performance liquid chromatography (HPLC).

The results of sampling and analysis showed that both temperature and $\mathrm{pH}$ are important process variables. In general, higher levels of bioactivity and subsequent rates of organic acid production were observed with operation at the higher temperatures. At a $\mathrm{pH}$ of 11, organic acid production was minimal, with overall inhibition apparently due to the high $\mathrm{pH}$. Some production of the undesirable organic acids also occurred at $\mathrm{pH} 11$. At $\mathrm{pH}$ 7, a higher production of organic acids was observed, with a higher percentage of the undesirable acids and minimal production of lactic acid. At $\mathrm{pH} 5$, lactic acid production was the highest observed along with minimal production of the undesirable acids. Organic acid production at $\mathrm{pH} 5$ and $98^{\circ} \mathrm{F}\left(37^{\circ} \mathrm{C}\right)$ is illustrated in Figure 5.

Lactic acid continued to show increases in concentration until approximately 6 to 8 days of incubation, suggesting that an optimal retention time occurs at approximately 6 days. Since the systems were operated in a batch mode, hydraulic retention time was equivalent to a mean cell residence time, or sludge age. After 6 to 8 days of incubation, lactic acid was observed to decrease, suggesting utilization as a substrate, possibly for methanogenesis.

In order to provide fermented samples for testing and evaluation of downstream unit operations, fresh samples of ACS flume water were collected and subjected to a larger-scale batch fermentation. A 5-gallon sample of clarified ACS flume water was collected and $\mathrm{pH}$ adjusted from the as-received $\mathrm{pH}$ of 10.3 to 5.5. The sample was maintained at $95^{\circ} \mathrm{F}\left(35^{\circ} \mathrm{C}\right)$, and the $\mathrm{pH}$ was adjusted daily to 5.5 . 


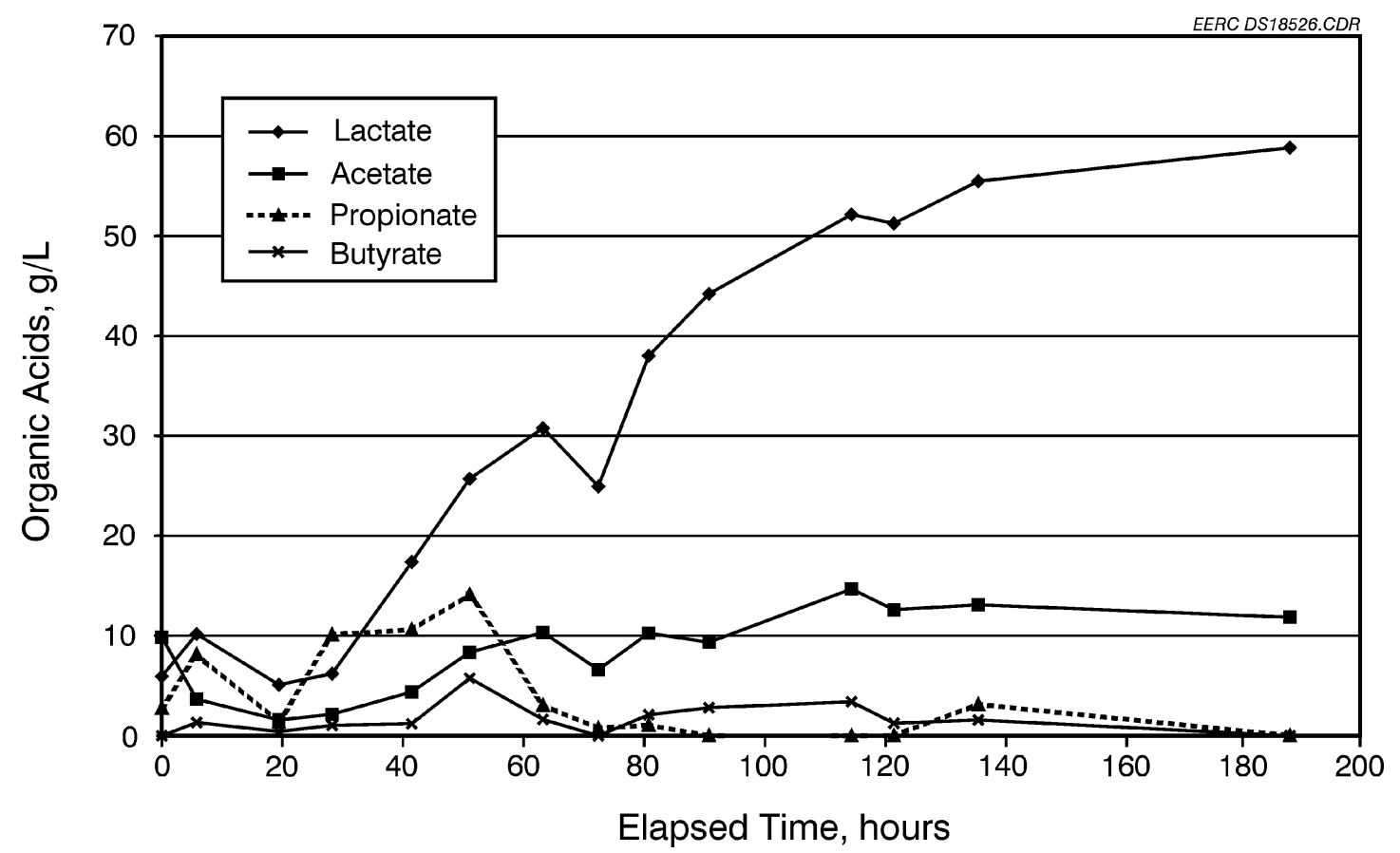

Figure 5. Organic acid production - ACS flume water at $98^{\circ} \mathrm{F}\left(37^{\circ} \mathrm{C}\right)$ and $\mathrm{pH} 5$.

\subsection{Continuous-Flow Testing}

Two types of continuous-flow systems were evaluated: suspended-growth with cell recycle and attached-growth. Operation of both systems was conducted on untreated (as collected) flume water and freeze-concentrated flume water. Initial operating conditions were designed to be readily integrated into existing factory operations. This included operation at a temperature of $98^{\circ} \mathrm{F}\left(37^{\circ} \mathrm{C}\right)$, the current heat exchange temperature. The systems were operated with increasing feed rates during an acclimation and stabilization period, until a 1-day hydraulic retention time (HRT) was achieved. Stable operation was observed in both systems between a 1- and 2-day HRT.

With continued operation on the untreated flume water at $98^{\circ} \mathrm{F}\left(37^{\circ} \mathrm{C}\right)$, both systems developed very high solids concentrations. A gradual reduction in effluent lactate was also observed. The high solids resulted in excessive growth that resulted in plugging of the attached growth system and mixed-liquor suspended solids as high as $20,000 \mathrm{mg} / \mathrm{L}$ in the suspended- growth system. These growth patterns were subsequently attributed to the adaptation and growth of Leuconostoc, bacteria that are resident in the soil and frequent sugar beet-growing and processing areas and store energy through extracellular polymerization of sugars to form dextrans, very high-molecular-weight polysaccharides. Operation of both systems at higher temperatures, ranging from $107^{\circ}$ to $122^{\circ} \mathrm{F}\left(42^{\circ}\right.$ to $50^{\circ} \mathrm{C}$ ) inhibited the growth of Leuconostoc and resulted in better overall lactic acid fermentation. 


\subsubsection{Suspended-Growth Fermentation}

A suspended-growth reactor system with cell recycle was evaluated as a fermentation method for the conversion of carbohydrates to organic acids. The suspended-growth system, shown in Figure 6 , consisted of a 4-L completely mixed reactor basin. The contents of the reactor were maintained in suspension via mechanical mixing. Influent was fed to the reactor at a controlled rate using a peristaltic pump. The contents of the reactor (mixed liquor) flowed by gravity to a secondary clarifier where biomass and settleable solids gravity-settled from the bulk

solution. Twice each hour, the settled solids were pumped back to the reactor to maintain the population of microorganisms in the reactor. Effluent from the system overflowed a centrally located weir and was collected in an effluent storage container.

Influent and effluent samples were collected routinely to assess process performance under several different operating conditions. A performance summary under pseudo-steady-state conditions treating flume water is presented in Table 2 .

Fermentation of flume water at higher temperature appeared to inhibit the growth of the undesirable Leuconostoc organism, resulting in higher levels of effluent lactic acid. These temperature conditions, however, also appeared to favor the growth of dispersed, non-floc-forming bacteria that resulted in poor settling as indicated by lower settleable solids and higher effluent suspended solids. The increased effluent lactic acid at the higher operating temperature can be attributed to the longer hydraulic retention time.

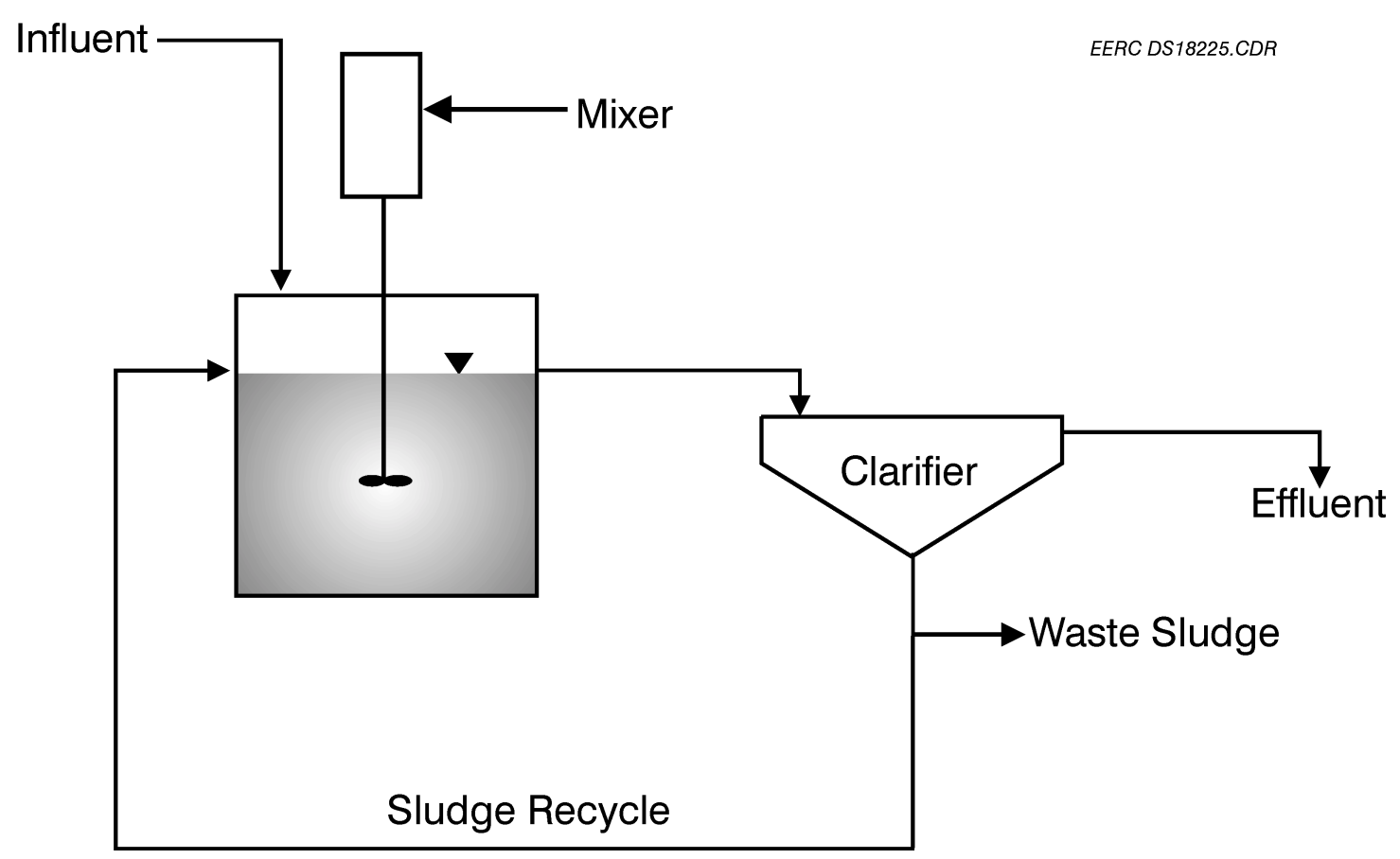

Figure 6. Suspended-growth fermentation process diagram. 


\section{TABLE 2}

Performance Summary - Suspended-Growth Fermentation

Flume Water Feed

\begin{tabular}{lcc}
\hline Temperature, $^{\circ} \mathrm{F}$ & 95 & 110 \\
$\mathrm{pH}$ & 5.7 & 6.0 \\
Hydraulic Retention Time, days & 1.07 & 2.5 \\
& & \\
Mixed-Liquor Suspended Solids, mg/L & 11,800 & 11,600 \\
Effluent Suspended Solids, mg/L & 3800 & 5700 \\
Settleable Solids, mL/L & 285 & 125 \\
& & \\
Effluent Organic Acids, g/L: & & \\
Lactic & 16.6 & 36.6 \\
Acetic & 6.3 & 5.9 \\
Propionic & 0.5 & 0.3 \\
Butyric & 0.1 & 0.8 \\
\hline
\end{tabular}

Suspended-growth fermentation test trials were also conducted using freeze-concentrated flume water. A performance summary under pseudo-steady-state conditions treating freezeconcentrated flume water is presented in Table 3. Freeze concentration of the flume water resulted in an average influent carbohydrate level of $248 \mathrm{~g} / \mathrm{L}$, as measured by analysis using the phenolsulfuric acid method. Effluent carbohydrates were $76,000 \mathrm{mg} / \mathrm{L}$, representing a relatively low level of consumption. Effluent lactic acid was slightly greater than $10 \%$, probably representing a level of microbial inhibition.

\subsubsection{Attached-Growth Fermentation}

An attached-growth fermentation system (Figure 7) was also evaluated as a method for the conversion of carbohydrates to organic acids. The attached-growth reactor consisted of a 4-inchdiameter, 2-L down-flow column containing packing media in the form of 1-inch-diameter $\times$ 1-inch-long Ryton Pall rings. The Ryton media has a surface area of $54 \mathrm{ft}^{2} / \mathrm{ft}^{3}$. Total estimated surface area of the reactor was $4 \mathrm{ft}^{3}$, including reactor sidewalls. Influent was fed to the top of the reactor through a peristaltic pump. Liquid was recycled at a rate of $500 \mathrm{~mL} / \mathrm{min}$ from the bottom of the reactor to the top and distributed across the packing with a tube drilled with holes along its length. The $\mathrm{pH}$ of the reactor was controlled to 5.5 with $10 \mathrm{M} \mathrm{NaOH}$ using a $\mathrm{pH}$ controller coupled with a peristaltic pump. Feed was metered to the reactor with a peristaltic pump from an influent container that was held at $37^{\circ} \mathrm{F}\left(3^{\circ} \mathrm{C}\right)$. 


\section{TABLE 3}

Performance Summary - Suspended-Growth Fermentation Freeze-Concentrated Flume Water Feed

\begin{tabular}{lc}
\hline Temperature, ${ }^{\circ} \mathrm{F}$ & 105 \\
$\mathrm{pH}$ & 6.0 \\
Hydraulic Retention Time, days & 6.04 \\
& \\
Settleable Solids, mL/L & 100 \\
& \\
Effluent Organic Acids, g/L: & \\
Lactic & 103.7 \\
Acetic & 6.3 \\
Propionic & 0.6 \\
Butyric & 1.9 \\
\hline
\end{tabular}

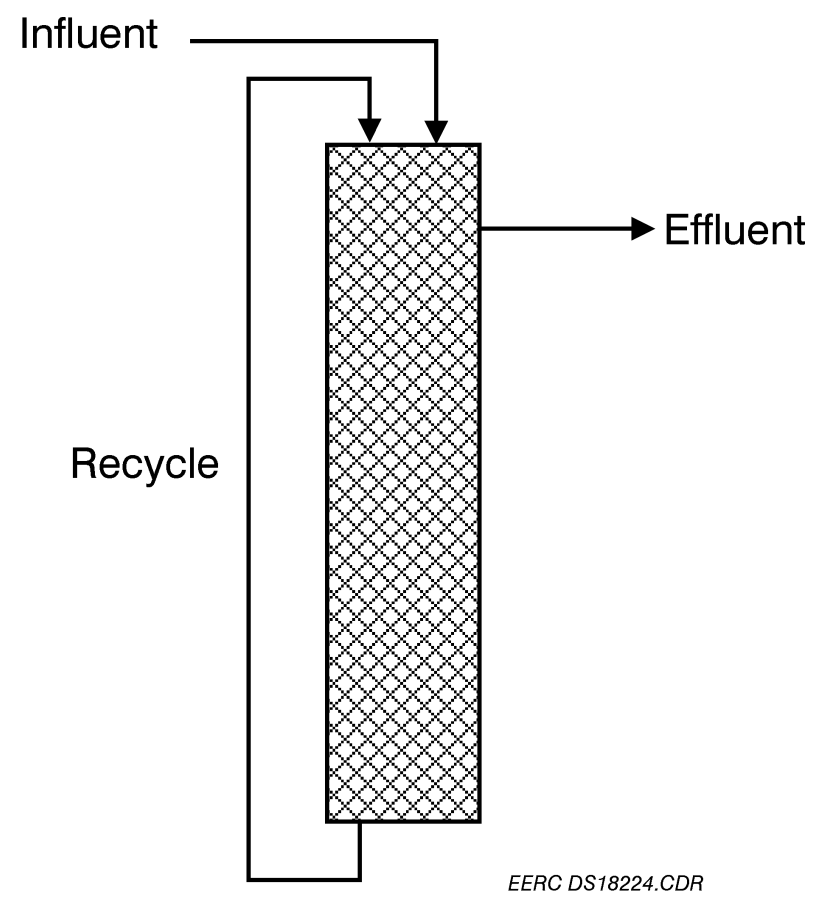

Figure 7. Attached-growth fermentation process diagram. 
The attached-growth system was operated at four sets of conditions. The $\mathrm{pH}$ was held constant in every case at 5.5. The feed in the first three cases was flume water fed at a rate of $1 \mathrm{~L} /$ day giving an HRT of 2 days. Three temperatures were tested: $97^{\circ}\left(36^{\circ} \mathrm{C}\right), 113^{\circ}\left(45^{\circ} \mathrm{C}\right)$, and $122^{\circ} \mathrm{F}\left(50^{\circ} \mathrm{C}\right)$. A fourth test was conducted with FT brine at a temperature of $122^{\circ} \mathrm{F}\left(50^{\circ} \mathrm{C}\right)$.

With operation at $97^{\circ} \mathrm{F}\left(36^{\circ} \mathrm{C}\right)$, the reactor eventually plugged with excessive growth of Leuconostoc. The temperature was subsequently increased to $113^{\circ} \mathrm{F}\left(45^{\circ} \mathrm{C}\right)$ which inhibited the growth of the Leuconostoc, resulting in improved operability. As indicated by the data in Table 4, lactic acid production increased with each increase in temperature, with effluent concentrations of 20,28 , and $36 \mathrm{~g} / \mathrm{L}$ corresponding to temperatures of $97^{\circ}\left(36^{\circ} \mathrm{C}\right), 113^{\circ}\left(45^{\circ} \mathrm{C}\right)$, and $122^{\circ} \mathrm{F}\left(50^{\circ} \mathrm{C}\right)$, respectively. The acetic acid production showed a decreasing trend with increasing temperature with effluent levels of 6,4 , and $1 \mathrm{~g} / \mathrm{L}$ at $97^{\circ}\left(36^{\circ} \mathrm{C}\right), 113^{\circ}\left(45^{\circ} \mathrm{C}\right)$, and $122^{\circ} \mathrm{F}\left(50^{\circ} \mathrm{C}\right)$, respectively. There was no apparent change in effluent propionic acid. Butyric acid decreased from $1 \mathrm{~g} / \mathrm{L}$ with operation at $97^{\circ} \mathrm{F}$ to $0.5 \mathrm{~g} / \mathrm{L}$ at both $113^{\circ}$ and $122^{\circ} \mathrm{F}\left(45^{\circ}\right.$ and $\left.50^{\circ} \mathrm{C}\right)$.

\section{TABLE 4}

Operating Data and Results Summary

\begin{tabular}{lcccc}
\hline Temperature, ${ }^{\circ} \mathrm{F}$ & 97 & 113 & 122 & 122 \\
$\mathrm{pH}$ & 5.5 & 5.5 & 5.5 & 5.5 \\
HRT, days & 2 & 2 & 2 & 2 \\
& & & & \\
Effluent Organic Acids, g/L: & & & \\
Lactic & 20 & 28 & 36 & 55 \\
Acetic & 6 & 4 & 1 & 2 \\
Propionic & 0 & 0 & 0 & 1 \\
Butyric & 1 & 0.5 & 0.5 & 1 \\
\hline
\end{tabular}

\subsection{RECOVERY/PURIFICATION}

Several options were evaluated with the objective of defining the requirements for lactic acid recovery. The various options were in response to process modifications to the development of the integrated lactic acid production and recovery system. These options and the project results are summarized below.

\subsection{Conventional Calcium Lactate Formation and Acidification}

Conventional lactate fermentation, such as that used by American Maize, employed hightemperature conditions with Lactobacillus delbruekii. Dextrose obtained by hydrolysis of starch was converted to the D,L-lactic acid mixture in about $85 \%$ yield, based on fermentable hexose sugar. Calcium carbonate was added to control $\mathrm{pH}$ during the fermentation, and additional lime was added 
at the end to complete the formation of calcium lactate, which is soluble at higher temperatures. The solution was decolorized with carbon, pressure filtered, and the filtrate evaporated. Sulfuric acid was added to the filtrate to liberate the lactic acid and form insoluble calcium sulfate. Further carbon treatment, filtration, and evaporation gave an edible-grade lactic acid. This product would contain some metal ions and soluble carbohydrates that would accompany the lactate.

The lime precipitation and subsequent sulfuric acid acidification process was applied to fermented brine solutions. The calcium salts produced by addition of lime were evaporated to dryness as in the conventional process. Sulfuric acid was added to the calcium salts in an ice-cooled vessel to minimize loss of lactic acid, since a considerable amount of heat is generated in the neutralization. The acid content of the product was determined by HPLC. The reactions produced lactic acid containing significant amounts of acetic and butyric acids. The amounts of acetic acid in the products from two fermentation experiments were $10 \%$ and $26 \%$ of the lactic acid amounts. These relative amounts corresponded with the relative concentrations produced in the fermentations. Thus there is no selectivity for lactic acid over acetic acid in the calcium precipitation. Butyric acid concentrations were considerably lower (3\% and $12 \%$ of lactic) in the recovered acids. There is some loss of butyric in the process. Thus removal of acetate and butyrate will be required for the product of fermentation using the indigenous organisms, unless the crude mixed-calcium salts are used for some inexpensive processing such as flue gas desulfurization (FGD) or coal cleaning (i.e., replacing sodium in the coal with calcium). In coal cleaning, the crude calcium lactate solution is applied to a bed of high-sodium coal, and calcium is exchanged for sodium, producing a coal with better combustion characteristics. This product, containing the acid mixture, will, however, be unacceptable for food-grade lactic acid.

\subsection{Acid/Ester Separations}

Several experiments were performed to separate the acids in the fermentation products. The fermentation product obtained using sodium hydroxide for neutralization was adjusted to a $\mathrm{pH}$ of 5 , and air was passed through the heated solution to attempt to selectively remove the more volatile acetic acid. At this $\mathrm{pH}$, part of the acetic will be present as acetic acid and part as sodium acetate. The initial composition of acids was $59 \%$ lactic, $21 \%$ acetic, and $20 \%$ butyric. This procedure failed to selectively remove the acetic acid, and, instead, some loss of all three acids was observed. The $\mathrm{pH}$ was lowered to 4 where more of the acetic acid form is present, but most of the lactic is the salt. When air was passed through the solution, only $64 \%$ of the acids were recovered from the flask, and the final concentration was $68 \%$ lactic, $26 \%$ acetic, and $6 \%$ butyric. Thus this method also failed to separate the acids.

The acid mixture obtained by calcium precipitation and sulfuric acid acidification was vacuum-distilled. Some of the water was removed initially. The acetic acid distilled out mainly in the first fraction, but it was still very impure, containing butyric and lactic acids as well as water. The presence of the water suggests that a lower-boiling azeotrope is forming that results in the impure acid mixture in the distillate. On raising the distillation temperature to obtain the lactic acid, some of the lactic decomposed, and much of it was converted to the oligomeric forms that do not distill. Thus all attempts to purify the lactic acid by distillation were unsuccessful. 
Formation and distillation of the methyl ester has been the preferred method for lactic acid purification. This not only removes the metal ions and carbohydrates, but also could separate the acid impurities, since the boiling points of the methyl acetate and methyl butyrate are much lower than those of the methyl lactate. This method was investigated by refluxing the acid mixture with methanol and a p-toluenesulfonic acid catalyst to form the methyl esters. Indeed the methyl acetate distills out easily in the first fraction with excess alcohol. The methyl butyrate also comes out in the early fractions, along with a small amount of the lactate ester. The methyl lactate mostly remains in the distillation pot. Similar results are obtained for the ethyl ester. This method is successful for separation of the acid mixtures, and no significant amount of the lactate is lost, owing to the formation of oligomeric esters or other decomposition products. The products do contain a large amount of the alcohol, however. The methyl lactate could be hydrolyzed back to pure lactic acid or could be used as a solvent or chemical intermediate. Alternatively, methanol vapor reactions on an acid catalyst column have been employed for conversion to methyl esters in high yield.

The esterifications are attractive owing to the high value of lactate esters $(\$ 4 / \mathrm{lb})$ and the relative ease of this process. The esters will be useful for solvents and for conversion to lactide or other polymer and plasticizer intermediates.

\subsection{Sodium Recycle, Calcium Lactate Precipitation}

The FT concentration process could be carried out with either the dilute sugar present in the flume water or the dilute acid products obtained after fermentation. However, when lime was used for neutralization during fermentation, precipitation of calcium lactate occurred during the FT processing of the fermentation product obtained. This second solid phase was difficult to collect, and redissolution into the melting ice resulted in loss of lactate. The solubility of the calcium lactate is $39 \mathrm{~g} / \mathrm{L}$ at low temperatures, so the excess of calcium lactate above this concentration will theoretically precipitate out. In one previous experiment with barrel-frozen and partially thawed fermenter water from calcium-controlled fermentation, this concentration was actually found. Calcium lactate precipitate was found in large amounts, but the quantity was not actually determined, and mass balance was unknown. During FT concentration of the flume water, only small amounts of calcium lactate are present and thus loss of solid-phase calcium lactate is not a problem.

To eliminate the calcium salt precipitation problem during FT concentration of the fermentation product, sodium hydroxide or sodium carbonate could be utilized in the fermentation for neutralization, since these will give the very soluble sodium lactate salt. Then to recover lactate from the brine concentrate obtained from sodium fermentation, lime must be added to the soluble sodium lactate concentrate to precipitate calcium lactate and form sodium hydroxide that can be recycled back to the fermenter. The sodium base is many times more expensive than the lime, necessitating its recovery.

The proposed sodium recovery-calcium lactate precipitation unit consists of several steps: adding to or mixing the lime slurry, stirring to effect reaction and precipitation, settling of the precipitate, and collecting the precipitate. This collection is followed by conversion of the precipitate to lactic acid, addition of concentrated sulfuric acid, and collection of the calcium sulfate produced. 
Further work was performed to establish the feasibility of recovering the excess of calcium lactate by lime addition in the post-FT base recycle unit rather than in the fermentation unit. Stoichiometric amounts of lime were added to the FT-concentrated sodium fermentation product at ambient temperatures. This brine product contained $12.9 \mathrm{wt} \%$ lactate, $3.4 \mathrm{wt} \%$ acetate, and $2.1 \mathrm{wt} \%$ butyrate as the sodium salts. The precipitation was allowed to proceed overnight at $32^{\circ} \mathrm{F}\left(0^{\circ} \mathrm{C}\right)$. A very thick paste (gel) was produced. Several attempts to vacuum filter the gel gave only a few $\mathrm{mL}$ of solution, however. A low-pressure filtration produced a small amount of solution. Centrifugation was also a failure. A high-pressure filtration device was constructed using a hydraulic press. This was successful in producing only about half the solution expected. The concentrations of acids in the filtrate (recycle solution) were determined and are reported in Table 5. The lactate concentration in the filtrate was $8.8 \%$, which was considerably higher than that expected based on the solubility product for calcium lactate $(3.9 \%)$.

\section{TABLE 5}

\begin{tabular}{|c|c|c|c|}
\hline \multirow[b]{2}{*}{ Test } & \multicolumn{3}{|c|}{ Filtrate Concentration, \% } \\
\hline & Lactate & Acetate & Butyrate \\
\hline Pure Lactate & 12.0 & 0 & 0 \\
\hline Ambient Press & 5.3 & 0 & 0 \\
\hline $32^{\circ} \mathrm{F}$ Press & 3.0 & 0 & 0 \\
\hline Initial Brine & 12.9 & 3.4 & 2.1 \\
\hline $32^{\circ} \mathrm{F}$ Press & 8.8 & 2.5 & 1.9 \\
\hline $0^{\circ} \mathrm{F}$ Press & 5.9 & 2.2 & 1.7 \\
\hline
\end{tabular}

To investigate the reason for higher lactate in the recycle filtrate, an experiment was conducted which involved adding lime to pure lactic acid at $12.0 \mathrm{wt} \%$. Filtration at $32^{\circ} \mathrm{F}\left(0^{\circ} \mathrm{C}\right)$ gave $3.0 \mathrm{wt} \%$ lactate in the filtrate, which was lower than expected. Filtration at $72^{\circ} \mathrm{F}\left(22^{\circ} \mathrm{C}\right)$ gave $5.3 \mathrm{wt} \%$, also lower than expected. Since the filtrate from the actual brine was higher than $3.9 \mathrm{wt} \%$, the problem could be attributed to the presence of the other calcium salts in the brine, whose presence interferes with the solubility of the calcium lactate gel.

A second brine sample was neutralized with a $10 \%$ excess of lime, and the precipitation allowed to occur over several days at $0^{\circ} \mathrm{F}\left({ }^{-} 18^{\circ} \mathrm{C}\right)$. Filtration was conducted at $0^{\circ} \mathrm{F}\left({ }^{-} 18^{\circ} \mathrm{C}\right)$. The concentration of the lactate in the brine from this experiment was $5.9 \%$, and the concentrations of the other components were correspondingly lower. Thus the lower temperature helped in the removal of calcium lactate, but the lactate in the recycle was still high.

To act as an aid in filtration, calcium sulfate was mixed with the calcium lactate gel before filtration. Filtration of the resulting mixture was still difficult and could not be carried out at low pressures. 
The difficulty of filtration and the low recovery of solution in the filtration as well as the higher concentration of lactate in the recycle solution mean that the sodium recycle is not a practical solution. Therefore, the FT concentration process should be performed with the flume water rather than the fermentation product.

\subsection{Polar Solvent Extraction}

The extraction of lactate and other acids from the fermentation solution was investigated with polar solvents. These extractions were performed in a batch process and could be adapted to a continuous extraction unit. The crude lactic acid could then be purified by esterification and distillation.

The results for extraction of lactic acid from a $3.9 \mathrm{wt} \%$ lactic acid solution $(\mathrm{pH} 3)$ with a 1:1 ratio of solvent to aqueous solution are reported in Table 6 . The results clearly demonstrate that the extraction with 1-butanol is superior. It would be anticipated that extraction of a fermentation product with 7\%-10\% lactic acid using continuous extractor with this solvent should extract more than $90 \%$ of the lactic acid. The main problem with this solvent is that a substantial amount of the 1-butanol will remain in the aqueous phase, owing to the relatively high water solubility of 1butanol. A second problem is that a relatively large solvent-to-water ratio is required, owing to the high solubility of lactic acid in water.

\section{TABLE 6}

\begin{tabular}{lc}
\multicolumn{2}{c}{$\begin{array}{c}\text { Extraction Yields from Flume Water } \\
(3.9 \% \text { Lactate })\end{array}$} \\
\hline Solvent & Remonic:Aqueous $=1: 1$ \\
\hline 1 - Butanol $\%$ \\
1- Octanol & 52 \\
Cyclohexanol & 4 \\
$t$ - Butanol & 36 \\
2 - Butanone & 41 \\
Diisopropyl Ether & 52 \\
Butyl Acetate & 5 \\
\hline
\end{tabular}

The efficiency for extraction of a $7.8 \%$ lactic acid fermentation product ( $\mathrm{pH} 2.5$ ) was determined using 1-butanol in a series of four successive extractions with a 1:2.5 ratio of solvent to aqueous solution. This procedure used a much smaller solvent-to-water ratio than the previous extractions. The results showed that a total of $65 \%$ of the lactic acid was extracted after the four stages. All the acetic and butyric were extracted from the fermentation product by the solvent in this series. This extract was directly esterified as described in the following section. 
The solubility of 1-butanol in the aqueous phase and its ease of recovery from the water was determined by distillation of the aqueous phase. The butanol-water azeotrope distilled at $199^{\circ} \mathrm{F}$ $\left(93^{\circ} \mathrm{C}\right)$, and then the temperature rose quickly to $212^{\circ} \mathrm{F}\left(100^{\circ} \mathrm{C}\right)$ where water came off. The distillate separated easily into two layers, the upper layer consisting of $7.6 \mathrm{~mL}$ of butanol and the lower 5.6 $\mathrm{mL}$ of water. Thus, because of the azeotrope formation, butanol could be easily recovered from the aqueous phase by steam stripping and separation of the overhead into the two layers.

Extraction of the fermentation product with diisopropyl ether was also attempted. An emulsion formed that prevented further work with ether solvents.

Owing to the success of the 1-butanol extraction and subsequent direct esterification, no other solvents were examined for the extraction of the fermentation products.

\subsection{Esterification/Distillation Combined with Extraction}

A convenient method was devised for purification of the acids extracted from the fermentation using 1-butanol. Earlier work showed that a mixture of acids was converted to the butyl esters, and the distillate was separated cleanly in a Dean-Stark apparatus to two layers, a water layer and a 1butanol-butyl acetate layer. Removal of water thus forces the esterification to completion. The remaining pot liquid was distilled under vacuum to give a small amount of distillate composed of butyl butyrate and butyl lactate. A second fraction consisted of $98 \%$ butyl lactate and $2 \%$ butyl butyrate.

A similar esterification was performed with the acid mixture obtained in the multiple extraction of fermentation product with the 1-butanol described in the previous section. Thus acid catalyst (p-toluenesulfonic acid) was added to the butanol solution, and the solution was refluxed for 2 hours. Dean-Stark distillation and subsequent vacuum distillation gave a $98 \%$ butyl lactate product.

The convenience in doing the esterification with the same solvent that is used in the extraction combined with the efficiency of water removal from the butanol in the Dean-Stark method and the ester separation make this the most cost-effective method for extraction and purification of the fermentation acids. Furthermore, the butanol residue in the water is easily recovered by steam stripping.

\subsection{Solvent Extraction with Amines}

The extraction with an amine solvent mixture as described in the Cargill patent and other literature has been extensively studied using the concentrates from fermentation and freeze crystallization. In batch studies, several successive extractions are needed to remove most of the lactate. This can be accomplished readily with a continuous or countercurrent extractor with as few

as four theoretical stages. Although partition coefficients differ, all the acids are extracted into the product phase, and most of the sugars, ions, and other impurities are left in the aqueous phase. A major disadvantage is that large amounts of amine solvent are required, equal to the aqueous volume. This means a large initial investment is required; however, very little solvent will be lost in the 
process. A second disadvantage is that it is not easy to remove the acids from the ammonium lactate intermediate and regenerate the amine solvent. Several options for this removal are described below.

\subsubsection{Back Extraction with $\mathrm{NaOH}$}

A back-extraction method using aqueous $\mathrm{NaOH}$ solution is described in the Cargill patent for removal of lactate from the amine solvent, so that the solvent can be recycled. Although this method was feasible, several disadvantages were notable. A large concentration of $\mathrm{NaOH}$ is required for the back-extraction, and more than one stage is required. This results in an excess of base in the product, and leaves a fairly dilute solution of lactate and other acids, which requires a substantial amount of acid for neutralization. This leaves the process where it started, because filtration and evaporation are needed for concentrating the lactate and other acids.

\subsubsection{Thermal Cracking of Ammonium Lactate Solution}

As also described in the Cargill patent, the amine solution can be heated and distilled to decompose the lactate salt and give a distilled lactic acid product. However, the required temperatures are high, and decomposition of the amine was noted. This contaminated the lactic acid produced. The separation of the other acids was also not complete in the distillation.

\subsubsection{Esterification of Ammonium Lactate Solution}

As in the direct esterification of the 1-butanol extract, the process involves a conversion of the ammonium lactate in the extract and other salts to the esters. This would not require the backextraction with $\mathrm{NaOH}$ and subsequent neutralization with sulfuric acid. Several experiments were performed to demonstrate the feasibility of this process.

Methanol and a large excess of sulfuric acid were added to the acid mixture in a triisooctylamine-decane solvent, and the mixture was refluxed for 2 hours. Excess methanol and decane were distilled out and the remaining material vacuum distilled. The products were highly impure, owing to decomposition of the lactic acid as well as the amine. A second experiment without the decane gave a similar highly impure mixture. A third experiment with ethanol instead of methanol gave another impure mixture. A fourth experiment with ethanol but containing only a small amount of sulfuric acid gave fractions containing expected amounts of ethyl acetate and ethyl butyrate-ethyl lactate mixtures. The ethyl lactate was impure.

A fifth experiment used ethanol and benzene instead of decane and somewhat more sulfuric acid. The benzene helped azeotrope out the water so that more ester formed. The initial fractions contained ethyl acetate and ethyl butyrate. Vacuum distillation gave an initial fraction with ethyl butyrate and ethyl lactate. The second fraction contained mainly ethyl lactate. In a sixth experiment, the benzene was not added until after refluxing. The ethyl esters were obtained in the distillation as before. When the distillation temperature was kept low, the amine did not decompose and could be recovered (as an ammonium sulfate form) and recycled to the extraction. It needs to be in the

ammonium form to effectively extract lactate from the fermentation solution. Although most of these reactions produced the desired esters, and ethyl lactate could be obtained, the conversions were not 
complete. Unreacted lactic acid was present in the distillation pot; as much as $53 \%$ of it was not converted.

Further work is needed to optimize the direct conversion of the amine extract to esters. The use of 1-butanol and Dean-Stark removal of water should facilitate high conversions to esters as observed in the 1-butanol extraction/esterification scheme. An alternative conversion using methanol vapor in a heated-acid catalytic column should be employed for conversion to the methyl esters.

\subsection{PROCESS CONCEPTUAL DESIGN}

As previously discussed, the overall process consists of freeze concentration, fermentation, and recovery and purification operations. Coupling these operations results in the process illustrated in Figure 8. Under this scenario, flume water (mud press water) is processed using the FT process to concentrate the carbohydrates in a brine. The carbohydrate concentration in both the flume water and brine will vary (increasing) throughout the beet-processing campaign. We have assumed an average total carbohydrate level of $27.5 \mathrm{~g} / \mathrm{L}$ based on COD levels observed during the 1999 campaign. Freeze concentration design criteria are listed in Table 7. Based on the results of laboratory testing, an estimated treated water yield of $80 \%$ of the total feed flow will result. The quality of the treated water will dictate its final use, which might be minimal treatment (the aeration basin of the existing wastewater treatment system) prior to discharge or in-plant reuse. Twenty percent of the total feed flow (200,000 gpd) will be captured as brine and directed through a heat exchanger to the fermentation reactor.

Fermentation design criteria, listed in Table 8, are based on an attached-growth system fed with a carbohydrate loading of 200,000 gpd at $125 \mathrm{~g} / \mathrm{L}$. Based on the results of bench-scale testing, a 2.5-day hydraulic retention time may be required. This is the equivalent of a 500,000-gallon fermentation vessel filled with a growth media with a surface area of at least $54 \mathrm{ft}^{2} / \mathrm{ft}^{3}$. Assuming a carbohydrate conversion to lactate of $64 \%$, as observed during bench-scale testing, an effluent lactate concentration of $80 \mathrm{~g} / \mathrm{L}$ would be expected. A neutralization requirement of approximately 80,000 $\mathrm{lb}$ /day of lime $(\mathrm{CaO})$ would be required to maintain a $\mathrm{pH}$ of 5.5. A fermentation temperature of $122^{\circ} \mathrm{F}\left(50^{\circ} \mathrm{C}\right)$ is recommended to avoid the growth of undesirable microorganisms, such as Leuconostoc.

Effluent from the fermentation reactor is directed to the lactate recovery/purification operations. Based on the results of bench-scale recovery and purification trials and previous experience of the investigators, the recommended recovery/purification process consists of solvent extraction, solvent recovery, esterification, and distillation operations. Preliminary design criteria for this scenario are presented in Table 9. Continuous-flow testing is still needed to verify these estimated design criteria. The process is based on the use of n-butanol as the solvent to extract lactate and other organic acid from fermentation effluent. The extraction is accomplished under acidic conditions, which requires an estimated 70,000 lb/day of sulfuric acid. Because lime is used for $\mathrm{pH}$ control during fermentation, the addition of sulfuric acid to reduce the $\mathrm{pH}$ results in the generation of an estimated 97,000 lb/day of calcium sulfate $\left(\mathrm{CaSO}_{4}\right)$. The impure $\mathrm{CaSO}_{4}$ produced can be recycled and used in factory operations. 


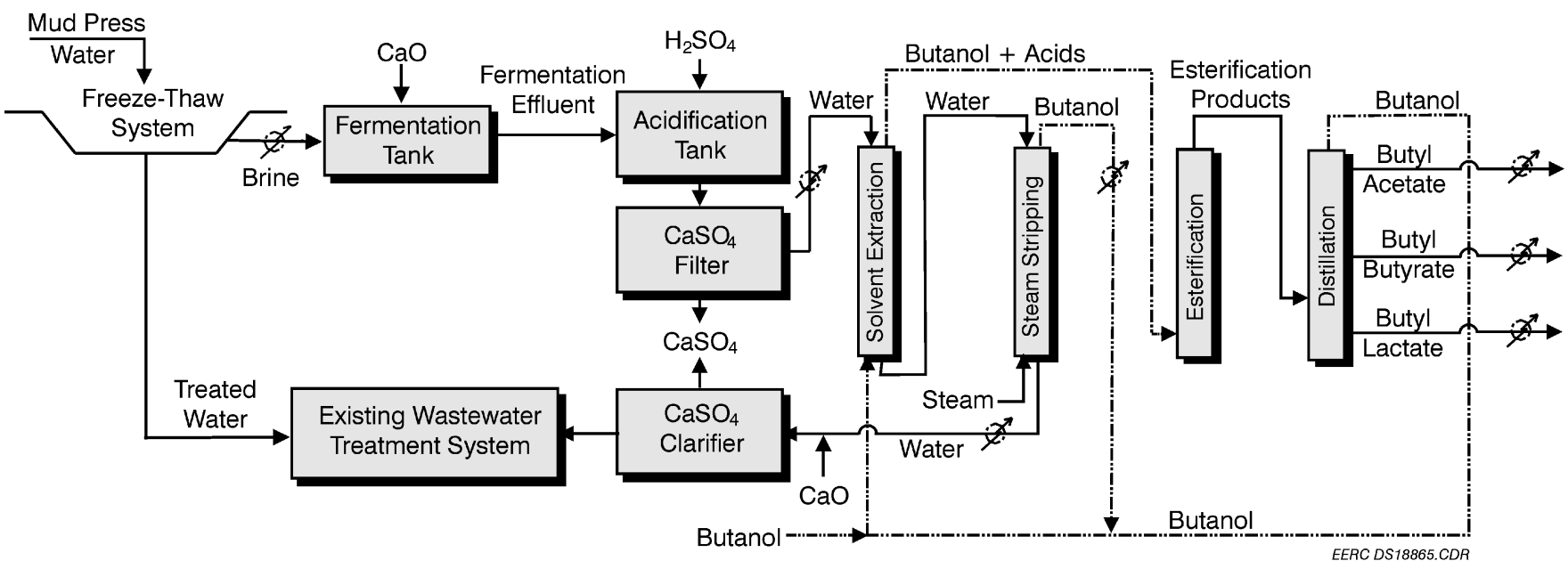

Figure 8. Process flow diagram. 


\section{TABLE 7}

Freeze Concentration Design Criteria

\begin{tabular}{ll}
\hline Feed Water Flow, gpd & $1,000,000$ \\
Feed Water Carbohydrates, mg/L & 27,500 \\
Treated Water Flow, gpd & 800,000 \\
Brine Flow, gpd & 200,000 \\
Brine Carbohydrates, mg/L & 125,000 \\
Cycles of Concentration & 5 \\
Land Area Required, acres & 55 \\
\hline
\end{tabular}

TABLE 8

Fermentation Process Design Criteria

\begin{tabular}{ll}
\hline Influent Flow, gpd & 200,000 \\
Average Influent Carbohydrates, mg/L & 125,000 \\
Reactor Volume, gallons & 500,000 \\
Hydraulic Retention Time, days $^{\circ}$ & 2.5 \\
Temperature, $^{\circ} \mathrm{F}$ & 122 \\
Average Effluent Lactate, $\mathrm{mg} / \mathrm{L}$ & 80,000 \\
Neutralization Requirement $(\mathrm{CaO}), \mathrm{lb} /$ day & 83,000 \\
\hline
\end{tabular}

TABLE 9

Recovery/Purification Design Criteria ${ }^{\mathrm{a}}$

Solvent Extraction

Water Flow, gpd

200,000

Solvent:Water Ratio, vol/vol

$1 / 16$

Solvent Recovery

Water Flow, gpd

200,000

Steam Flow, lb:gal

1.2

Esterification

Alcohol Requirement (butanol), gpd 15,600

Distillation Products

Butyl Lactate, lb/day

193,500

Butyl Acetate, lb/day

14,400

Butyl Butyrate, lb/day

4900

\footnotetext{
${ }^{a}$ Design criteria are based on previous experience and batch testing results. Continuous-flow testing is needed to verify these estimates.
} 
Solvent extraction is a countercurrent flow of 200,000 gpd of fermentation effluent being directed to the top of the extraction column with a solvent flow of 12,500 gpd of butanol entering at the bottom of the column. Organic acids are extracted from the water to the solvent in several mixing zones within the column. The solvent, along with extracted organic acids, exit the top of the column and are directed to an esterification reactor. Water, along with some dissolved butanol, flow out of the bottom of the column and are directed to solvent recovery. Solvent recovery is a separation accomplished using steam-stripping techniques to volatilize the butanol which is recycled back to the solvent extraction column.

The esterification process also utilizes butanol as the alcohol to produce butyl esters. The use of butanol as the solvent for extraction as well as the alcohol to produce the esters dramatically improves process efficiency and favorably impacts the economics of the recovery/purification process. The esters are produced with heat in using a solid-phase acid catalyst to drive the reaction. The butyl esters, unlike the original organic acids, have enough difference in boiling points that they can be readily separated by fractional distillation. Excess butanol is also separated during fractional distillation and is recycled back to the solvent extraction operation.

Assuming 95\% recovery of the organic acids during solvent extraction, 95\% conversion of those acids to butyl esters, and $99 \%$ recovery of the esters during distillation, the estimated products are 193,500 lb/day of butyl lactate (target product), 14,400 lb/day of butyl acetate, and $4900 \mathrm{lb} /$ day of butyl acetate.

\subsection{ECONOMIC CONSIDERATIONS}

Process economics were evaluated with a comparison of costs to revenue. The results of the economic analysis are shown in Table 10. Capital costs are presented for the individual operations as well as costs for product storage. Detailed capital cost data are listed in Table 11. The capital costs listed for the FT operation were obtained from a bid from Northern Watertek Corporation using its Snowfluent ${ }^{\circledR}$ process. Capital costs for fermentation, lactate recovery, and product storage and handling were based on preliminary vendor estimates. Capital costs $(\$ 10,550,000)$ were amortized over a 5-year period at an interest rate of $9 \%$, resulting in an annual payment of $\$ 2,712,325$ for 5 years.

Operating and maintenance cost detail is provided in Table 12 and includes estimates of electrical consumption, labor, maintenance, consumables, and chemical costs for the respective operations. The total annual operating and maintenance costs are estimated to be $\$ 8,347,800$.

Potential revenue was determined based on the butyl lactate production at a unit value of $\$ 0.63 / \mathrm{lb}$. Butyl lactate has a current market price of $\$ 1.74 / \mathrm{lb}$, but there are no published data to evaluate the market at that price. The $\$ 0.63 / \mathrm{lb}$ value is based on the price of methyl isobutyl ketone (MIBK), which represents a solvent that could be replaced by butyl lactate. The market for MIBK is 190 million $\mathrm{lb} / \mathrm{yr}$. At a unit value of $\$ 0.63 / \mathrm{lb}$, the revenues from butyl lactate are estimated to be over $\$ 14,600,000 / y r$. 
TABLE 10

ACS Lactic Acid Recovery Project

COST TOTAL

\section{Capital Cost}

Fermentation

$\$ 825,000$

Freeze-Thaw

$\$ 3,200,000$

Lactate Recovery

$\$ 3,675,000$

Product Storage/Handling

$\$ 2,850,000$

Total Capital Cost

$\$ 10,550,000$

Capital Amortization

Principal

$\$ 10,550,000$

Interest Rate

Life of Loan, years

$9 \%$

Salvage Value

5

Annual Payment

$\$-$

$\$ 2,712,325$

Total Cost of Loan

$\$ 13,561,627$

$\$ 2,712,325$

Operating and Maintenance (O\&M) Costs

Fermentation

$\$ 600,000$

Freeze-Thaw

$\$ 220,000$

Lactate Recovery

Product Storage/Handling

$\$ 7,080,200$

$\$ 97,600$

$\$ 350,000$

Lost Revenue from Anamet Methane

$\$ 8,347,800$

$\$ 8,347,800$

$\$ 11,060,125$

Total Annual Cost (capital + O\&M)

REVENUE TOTAL

Butyl Lactate Production Rate, lbs/day

193,500

Length of Operation, days/year

120

Total Annual Butyl Lactate Produced, lb

$23,220,000$

Butyl Lactate Unit Value

$\$ 0.63$

Total Annual Butyl Lactate Revenue

$\$ 14,628,600$

$\$ 14,628,600$

$\$ 3,568,475$

ADDITIONAL POTENTIAL REVENUE

Annual Revenue from other Lactate Products

lb/day $\$ / \mathrm{lb}$

$14,400 \quad \$ 0.61$

$\$ 1,054,080$

Butyl Acetate

$4900 \$ 0.50$

$\$ 294,000$

TOTAL

$\$ 1,348,080$

GRAND TOTAL ANNUAL PROFIT

$\$ 4,916,555$ 
TABLE 11

Capital Cost Detail

\begin{tabular}{|c|c|c|c|c|c|}
\hline Freeze-Thaw & & & & & \\
\hline Description & Quantity & Unit Cost & Units & Total & \\
\hline Retention/Equalization Pond & 1 & $\$ 430,000$ & Each & $\$ 430,000$ & \\
\hline Earthwork & 1 & $\$ 130,000$ & Lump & $\$ 130,000$ & \\
\hline Buildings & 1 & $\$ 140,000$ & Lump & $\$ 140,000$ & \\
\hline Electrical & 1 & $\$ 25,000$ & Lump & $\$ 25,000$ & \\
\hline Miscellaneous & 1 & $\$ 25,000$ & Lump & $\$ 25,000$ & \\
\hline FT Equipment (by Northern Watertek) & 1 & $\$ 2,450,000$ & Lump & $\$ 2,450,000$ & \\
\hline Freeze-Thaw Subtotal & & & & $\$ 3,200,000$ & $\$ 3,200,000$ \\
\hline Fermentation & & & & & \\
\hline Description & Quantity & Unit Cost & Units & Total & \\
\hline $\begin{array}{l}\text { Fermentation Reactor } \\
(500,000 \text { gallon, } \mathrm{SS})\end{array}$ & 1 & $\$ 350,000$ & Each & $\$ 350,000$ & \\
\hline Foundation and Insulation & 1 & $\$ 100,000$ & Lump & $\$ 100,000$ & \\
\hline $\begin{array}{l}\text { CaO Storage Tank (includes } \\
\text { foundation and dust collection) }\end{array}$ & 1 & $\$ 100,000$ & Each & $\$ 100,000$ & \\
\hline Electrical & 1 & $\$ 25,000$ & Lump & $\$ 25,000$ & \\
\hline Pumps/Piping/Valves & 1 & $\$ 100,000$ & Lump & $\$ 100,000$ & \\
\hline Controls and Sensors & 1 & $\$ 100,000$ & Lump & $\$ 100,000$ & \\
\hline Buildings & 1 & $\$ 50,000$ & Lump & $\$ 50,000$ & \\
\hline Fermentation Subtotal & & & & $\$ 825,000$ & $\$ 825,000$ \\
\hline Lactate Recovery & & & & & \\
\hline Description & Quantity & Unit Cost & Units & Total & \\
\hline Lactate Recovery Equipment & 1 & $\$ 3,500,000$ & Lump & $\$ 3,500,000$ & \\
\hline Electrical & 1 & $\$ 25,000$ & Lump & $\$ 25,000$ & \\
\hline Pumps/Piping/Valves & 1 & $\$ 75,000$ & Lump & $\$ 75,000$ & \\
\hline Controls and Sensors & 1 & $\$ 75,000$ & Lump & $\$ 75,000$ & \\
\hline Lactate Recovery Subtotal & & & & $\$ 3,675,000$ & $\$ 3,675,000$ \\
\hline Product Storage/Handling & & & & & \\
\hline Description & Quantity & Unit Cost & Units & Total & \\
\hline $\begin{array}{l}\text { Butyl Lactate Storage Tank }(3,000,000 \\
\text { gallon, SS) }\end{array}$ & 1 & $\$ 2,250,000$ & Each & $\$ 2,250,000$ & \\
\hline $\begin{array}{l}\text { Butyl Acetate Storage Tank }(300,000 \\
\text { gallon, SS) }\end{array}$ & 1 & $\$ 225,000$ & Each & $\$ 225,000$ & \\
\hline $\begin{array}{l}\text { Butyl Butyrate Storage Tank }(100,000 \\
\text { gallon, SS) }\end{array}$ & 1 & $\$ 75,000$ & Each & $\$ 75,000$ & \\
\hline Foundation for Product Storage Tanks & 1 & $\$ 150,000$ & Lump & $\$ 150,000$ & \\
\hline Pumps/Piping/Valves & 1 & $\$ 125,000$ & Lump & $\$ 125,000$ & \\
\hline Electrical & 1 & $\$ 25,000$ & Lump & $\$ 25,000$ & \\
\hline Product Storage/Handling Subtotal & & & & $\$ 2,850,000$ & $\$ 2,850,000$ \\
\hline TOTAL CAPITAL COST & & & & & $\$ 10,550,000$ \\
\hline
\end{tabular}




\section{TABLE 12}

O\&M Cost Detail

\begin{tabular}{|c|c|c|c|c|c|}
\hline \multicolumn{6}{|l|}{$\overline{\text { Freeze-Thaw }}$} \\
\hline Description & Quantity & Unit Cost & Units & Total & \\
\hline $\begin{array}{l}\text { Electrical Usage } \\
\quad \text { (730-kW load, } 1800 \text { hours of operation) }\end{array}$ & $1,312,500$ & $\$ 0.08$ & $\mathrm{kWh}$ & $\$ 105,000$ & \\
\hline Labor & 1 & $\$ 40,000$ & Lump & $\$ 40,000$ & \\
\hline Maintenance & 1 & $\$ 50,000$ & Lump & $\$ 50,000$ & \\
\hline Consumables & 1 & $\$ 20,000$ & Lump & $\$ 20,000$ & \\
\hline Testing/Sampling & 1 & $\$ 5000$ & Lump & $\$ 5000$ & \\
\hline Freeze-Thaw Subtotal & & & & $\$ 220,000$ & $\$ 220,000$ \\
\hline \multicolumn{6}{|l|}{ Fermentation } \\
\hline Description & Quantity & Unit Cost & Units & Total & \\
\hline $\begin{array}{l}\text { Electrical Usage } \\
\text { (250-kW load, } 2880 \text { hours of operation) }\end{array}$ & 720,000 & $\$ 0.08$ & $\mathrm{kWh}$ & $\$ 57,600$ & \\
\hline Labor & 1000 & $\$ 25.00$ & Lump & $\$ 25,000$ & \\
\hline Maintenance & 1 & $\$ 100,000$ & Lump & $\$ 100,000$ & \\
\hline Consumables & 1 & $\$ 19,000$ & Lump & $\$ 19,000$ & \\
\hline Chemicals $(\mathrm{CaO}, 83,000 \mathrm{lb} /$ day, 120 days $)$ & $9,960,000$ & $\$ 0.04$ & $\mathrm{lb}$ & $\$ 398,400$ & \\
\hline Fermentation Subtotal & & & & $\$ 600,000$ & $\$ 600,000$ \\
\hline \multicolumn{6}{|l|}{ Lactate Recovery } \\
\hline Description & Quantity & Unit Cost & Units & Total & \\
\hline $\begin{array}{l}\text { Electrical Usage } \\
\text { (250-kW load, } 5000 \text { hours of operation) }\end{array}$ & $1,250,000$ & $\$ 0.08$ & $\mathrm{kWh}$ & $\$ 100,000$ & \\
\hline Labor & 3000 & $\$ 25.00$ & Lump & $\$ 75,000$ & \\
\hline Maintenance & 1 & $\$ 100,000$ & Lump & $\$ 100,000$ & \\
\hline Consumables & 1 & $\$ 30,000$ & Lump & $\$ 30,000$ & \\
\hline Chemical (n-Butanol, 110,000 lb/day, 120 days) & $13,200,000$ & $\$ 0.50$ & $\mathrm{lb}$ & $\$ 6,600,000$ & \\
\hline Chemical $\left(\mathrm{H}_{2} \mathrm{SO}_{4}, 73,000 \mathrm{lb} /\right.$ day, 120 days $)$ & $8,760,000$ & $\$ 0.02$ & $\mathrm{lb}$ & $\$ 175,200$ & \\
\hline Lactate Recovery Subtotal & & & & $\$ 7,080,200$ & $\$ 7,080,200$ \\
\hline \multicolumn{6}{|l|}{ Product Storage/Handling } \\
\hline Description & Quantity & Unit Cost & Units & Total & \\
\hline $\begin{array}{l}\text { Electrical Usage } \\
\text { (250-kW load, } 2880 \text { hours of operation) }\end{array}$ & 720,000 & $\$ 0.08$ & $\mathrm{kWh}$ & $\$ 57,600$ & \\
\hline Maintenance & 1 & $\$ 40,000$ & Lump & $\$ 40,000$ & \\
\hline Product Storage/Handling Subtotal & & & & $\$ 97,600$ & $\$ 97,600$ \\
\hline O\&M SUBTOTAL & & & & & $\$ 7,997,800$ \\
\hline
\end{tabular}


Additional revenue can be realized from the other butyl esters that are produced along with the lactate. Based on data generated during bench-scale testing, 14,400 lb/day of butyl acetate and 4900 $\mathrm{lb} /$ day of butyl butyrate would be produced at unit values of $\$ 0.61 / \mathrm{lb}$ and $\$ 0.50 / \mathrm{lb}$, respectively. This represents additional annual revenue of $\$ 1,348,000$. A detailed market evaluation for these products is warranted. It is anticipated that the market for the organic ester solvents will increase owing to their biodegradable, nontoxic characteristics.

\subsection{CONCLUSIONS}

This project has shown that the recovery of several valuable lactic acid products is both technically feasible and economically viable. One of the original objectives of this project was to recover lactic acid. However, the presence of a variety of indigenous bacteria in the wastewater stream and technical issues related to recovery and purification have resulted in the production of lactic acid esters. These esters could by hydrolyzed to lactic acid, but only with unacceptable product losses that would be economically prohibitive.

The developed process is projected to produce approximately 200,000 $\mathrm{lb}$ per day of lactate esters from wastewater at a single factory at costs that compete with conventional solvents. The lactate esters are good solvents for polymers and resins and could replace acetone, methyl ethyl ketone, MIBK, and other polar solvents used in the polymer industry. Because of their low volatility and viscosity-lowering properties, they will be especially useful for inks for jet printers, alkyd resins, and high-solid paints. Owing to their efficiency in dissolving salts and flux as well as oils and sealants, lactate esters can be used in cleaning circuit boards and machine and engine parts. Unlike conventional solvents, lactate esters exhibit low toxicity, are biodegradable, and are not hazardous air pollutants.

Another application for lactate esters is in the production of plasticizers. Severe health problems have been attributed to widely used phthalate ester plasticizers. The U.S. Department of Agriculture showed that replacement of these with inexpensive lactate esters is feasible, owing to their superior polymer compatibility properties.

A very large market is projected for polymers prepared from lactic acid. These are called polylactides and are a type of polyester. Thermoplastics of this type have a variety of uses, including moldings, fibers, films, and packaging of both manufactured goods and food products. Polylactides form tough, orientable, self-supporting thin films and have, therefore, been used for adhesives, safety glass, and finishes.

If the bacterial culture produces the L-lactic acid enanatiomer form exclusively, the L-lactide prepared from this form can be used for making polymers with good fiber-forming properties. We have not currently achieved the exclusive production of L-lactate in our efforts. However, markets in films and structural shapes are available for polymers and copolymers prepared from the mixed D,L-lactide forms that result from processing the D,L-lactic acid obtained from fermentation such as that occurring naturally in sugar beet wastewater. These materials are slowly biodegraded to harmless compounds in the environment, and they burn with a clean blue flame when incinerated. 
These materials represent excellent opportunities for utilization of the D,L-lactic mixture produced from natural fermentation of the ACS flume water. Esters can be converted into a lactide, and the alcohol released from the ester can be recycled with no net consumption of the alcohol. Lactide intermediates could be produced locally and shipped to polymer producers elsewhere. The polymer and copolymer markets are extremely large, and the role of lactides in these markets is continuously expanding.

The overall process can be readily integrated into existing factory wastewater operations. There are several environmental benefits that would be realized at the factories with incorporation of the lactate recovery process. The process reduces the organic loading to the existing wastewater treatment system that should result in enhanced operability with respect to both solids handling and treated-water quality. A higher-quality treated water will also help reduce odor levels from holding ponds. Several water reuse opportunities are probable, depending on the quality of treated water from the FT process. 